\title{
東北大震災復興に見る地籍情報の重要性
}

\section{The importance of cadastral information in case of The Tohoku}

\author{
disaster.
}

\author{
鈴木 修 ${ }^{1 * 2}$ \\ Osamu SUZUKI ${ }^{1 * 2}$
}

1 宮城県土地家屋調查士会

Miyagi Land and House Investigators Assosiation

テ980-0802 宮城県仙台市青葉区二日町18番3号

2 鈴木修土地家屋調査士事務所

Osamu Suzuki Land and House Investigators Office

干980-0802 宮城県仙台市青葉区二日町16番20号

E-mail: mucha@rr.iij4u.or.jp

*連絡先著者 Corresponding Author

不動産は国土の狭い日本において重要な財産であり、その利活用はあらゆる産業の基盤となる。 であるから地籍の管理と活用は国家としても、個人としても重要な課題である。地籍情報とは測 地的数值情報と法的権利情報とそれぞれの履歴情報など複合的な情報を含んでいる。過去日本の 大学において伝統的な学問は、理科系と文科系に大別されており、地籍に関する研究も本来複合 的な要素を持ちながら、これまでは法律的アプローチと測地的アプローチとの二元的な研究をさ れていた。また阪神淡路大震災や一昨年の東日本大震災を経て、地籍情報は新たな課題も得た。 一方では筆界移動と権利の客体の問題であり、もう一方では防災減災という観点からの問題であ る。土地家屋調査士は不動産の表示に関する専門家であるが、近年は地籍情報を扱う法律と測量 の専門家としての役割がクローズアップされている。日ィフィールドに出て調査し、法律問題を 考える土地家屋調査士は、この法学と測地学の間をつなぐ役割を担うと考える。今回の東日本大 震災では、地款が最大 $5.85 \mathrm{~m}$ 東南方向に、-1.14 m 下方に移動した。測地的数值情報と しては、基準点の再測をして移動方向と移動量を把握して、その変動を管理できるし、筆界移動 についての方針が法務省から出されている。しかし、その土地の上に生じ始めている権利の問題 には今だに明確な答えはない。またこれまで地籍情報としては重要視されていなかった歴史的地 物や字名などの地名情報や民間伝承も、地籍情報として重要な情報だったことがわかった。過去 日本の学会は、地籍情報としてほんの一部を取り扱っていたようだ。今後想定されている新たな 
災害に対する備えのためにも、新たな国土構築のためにも、地籍研究はもっと広い範囲を取り扱 うべきだと考える。そしてこれらの複合的な地籍情報は、情報知識学の分野からも取り扱うべき と考える。

The Real Estate is important property in narrow Japan, and its conjugation consist a base imformation of any industrials. It means the conjugation and management of cadastre is important tasks as governmental and personal. Cadastral information includes geodesic numerical value, legal rights, and compositive information such as each archival records. Cadastre has been researched by 2 ways which are geodesic and legal with a basically chemistry, because its traditional researching were divided into arts course and science course at Japanese colleges in the past. In addition, some tasks of cadastre are coming up from experiences of Hanshin Big Earthquake and Tohoku Big Earthquake 2 years ago.

Which is the problems of boundaries removing and object for rights, and another one is the problem about cutting down damages by a disaster and protecting our life from a disaster.

Land and house investigator is active in property registration in Japan, and recently draw attention as the legal professtional of surveying who have knowledge of cadastre. Land and house investigator who ordinally survey at the field and consider the legal problems assume a role of connecting between jurisprudence and surveying.Earth crust moved 5.85m max to south east, went down $-1.14 \mathrm{~m}$ because of this disaster. We can manage the movement value because of we defined values of movement and its angle as a geodesic numerical value by re-surveying primary control marks, and Ministry of Justice published the policy about land moving. But we have had no clear answer yet about rights problem which are getting out on affected properties. We found that neglect histrial obuject as cadastral marks, geographical name (ex. village name), and traditional stories about the land, which are important cadastral information. Japanese academic society researched a only part of cadastre in the past. For Preparing for new disasters we know will come, and keeping up new spatial data, I believe researching about Japanese cadastre should have bigger range of knowledge, we should think about this compositive cadastre more at the JSIK. 


\section{1 地籍情報管理の複合性}

日本における地籍理論とその情報管理と しての各種手続きは、長年の歴史の積み重稌 の上で安定していると考えられる。地籍情報 とは測地的数值情報と法的権利情報とそれ ぞれの履歴情報など複合的な情報を含んで いる。国家としての地籍の管理は、測地的数 值情報管理の大元は国土交通省国土地理院 であり、地籍の法的権利情報管理は法務省法 務局で行っている。一方、過去日本の大学に おいて伝統的な学問は、理科系と文科系に大 別されており、地籍に関する研究も本来複合 的な要素を持ちながら、これまでは法律的ア プローチと測地的アプローチとの二元的な 研究をされていた。近年は平成 19 年施行の 地理空間情報活用推進基本法をもとに地籍 情報を産官学が相互利用できるように整備 する方針が出た。これは我が国独自の準天頂 衛星による衛星測位システムの推進も背景 にある。

さて、不動産登記情報の分野では、平成 1 7 年の不動産登記法改正に伴い、日本の登記 の表題部の根拠になる法 14 条 1 項地図は 電子情報で管理するように改正された。これ も日本の登記情報が世界標準の地籍情報と して利用する為には不可欠な事であった。し かし、平成 25 年の現在でも、国土交通省の 地籍データと法務省の地籍データのフォー マットは各々別のものを使っていて、地理空 間情報として一元的にその情報を取り扱う ことは簡単ではない状況にある。地籍学とい う分野も日本では確立しているとは言えず、 法学的な側面の学会と測地学的側面の学会 が各々研究を重初ている。最近相互乗り入れ 的な研究会は存在するが、現在地籍学会とい う学会は無い。地籍は複合的な情報であり、 それぞれの要素に専門家が必要な事は当然
だが、その専門家を結ぶアプローチも必要で あると考える。多様な専門家が集まるこの情 報知識学会がその役割を担う可能性がある と考える。

\section{2 地籍における土地家屋調査士の}

\section{役割}

土地家屋調査士という資格は、土地家屋調 査士法を根拠として1950 年に発足し、6 0 年を超える長きに渡り不動産の表示に関 する登記、測量調査の専門家として日本の登 記を支えている。監督官庁は法務省である。 土地家屋調査士法第 3 条 (業務) の中の「不 動産の表示に関する登記について必要な土 地又は家屋に関する調査又は測量」（同条第 1項第1号）「不動産の表示に関する登記の申 請手続（後略）」（同第 2 号）の目的とは、 権利の登記の前提として、まず権利の客体で ある不動産を調查し的確な登記情報を作成 する事にある。その為には、土地家屋調査士 は不動産登記に必要な各種法律知識と測量 技術を有しなければならず、その資格試験で も、やはり法律と測量が要求される。

長年の権利の客体として不動産を見て来 た専門家としての経験により、近年の土地家 屋調査士は筆界調査の役割が増加し、組織と しても境界の裁判外紛争解決機関を持ち、そ の紛争解決の代理人として活躍する立場も 法定されている。法的権利を意識しながら測 地情報を扱う唯一の資格である土地家屋調 査士は、地理空間情報推進の時代になり、そ の役割がクローズアップされている。日タフ ィールドに出て調査し、法律問題を考える土 地家屋調査士は、新しい時代の地籍における 法学と測地学の間をつなぐお手伝いができ 
ると考えている。

\section{3 東日本大震災で生じた地籍の新}

\section{たな問題}

権利の客体である不動産が盤石でなけれ ば、安心してあらゆる産業の基盤には成り得 ない。そうであるから筆界は動かないことが 法的にも原則である。過去の判例や通達も、

「隣接者お互いの合意のみで筆界は動かな い」「崖崩れ等の地表面の移動で筆かは動か ない」という原則である。しかし、平成 7 年 の阪神淡路大震災と平成 23 年の東日本大 震災で、登記と地籍は新たな課題を見せつけ られた。不動であるはずの土地が動いた。実 際に東日本大震災では水平方向東に 5.85 m（その後の余動で $6 \mathrm{~m}$ を超える）、鉛直方向 にー1.14 m動いている。国はすぐに基準 点を最測し、7 ケ月後に新たな成果を公表し た。新たな公共測量等はその成果に基づき測 量される事になった。問題は既存の地図であ る。基本的には新たな基準点成果に基づきパ ラメータが与えられ、変換計算をすることで 既存地図を利用する事にした。確かに被災地 すべての地図を再調査する事は実質的に不 可能であろう。しかし、これらの大規模移動 を単なる座標のパラメータ変換だけで処理 して良いのだろうか。実際に地図は権利の客 体を特定する意味も持っている。パラメータ 変換をした境界点が、現実的な地形や地物の 位置に来ない事例も多い。これは 1 筆 1 筆を 調查している土地家屋調査士が多数の事例 を持っている。こういった場合、国の発表し た数值情報としては問題ないし、筆界につい ても行政に責任は無いだろう。しかし公法上 の境界である筆界は決まっても、権利の境界
については現実的にトラブルになる可能性 はとても高い。東日本大震災からの復興の為 にも各々の持ち場を超えて議論し、問題提起 して、何らかの結論を出すことが急務であろ うし、災害の多いこの日本に住んでいる限り、 この議論は避けて通れないであろう。

\section{4 地籍情報と歴史的情報}

今回の東日本大震災で被害を調べている とあることに気がついた。津波で被災した 建物の所在の地名である。あるとき依頼を 受けて調査した建物の所在は字「流」であ った。また「割波」、「汐入」、「荒浜」等々 も経験した。普段は何気なく読んでいる地 名も、先人の残したとても重要な情報であ ることに改めて気がついた。地名は単なる 符号ではない。先人が地形や出来事を元に 名付けた固有名詞である。再度検証してみ ると「水」に関係する地名が多いことに気 がついた。また被災地には昔の津波を示す 波分神社や多くの石碑が残されている。こ れらの多くの史跡や民間伝承などは、現代 では大袈乷とか迷信の類いと考えられて、 研究対象としては理科系分野でも文科系分 野でもあまり重要視していなかった。しか し、今回の大震災でその多くには根拠が有 ったことが見直されている。

東日本大震災で何度も言われた「理論に おける想定外」だが、過去のこのような事 例を真摰に受け入れていたら決して想定外 にはならないはずだった。今後は、防災の 為にも、このような地名や史跡、民間伝承 なども、重要な地籍情報として再度科学の 眼で地形と比べながら見直す必要がありそ うだ。土地家屋調査士の持っている不動産 に関する法律知識と測量技術、それに業務 
として毎日のように蓄積される個々の膨大 な地籍情報、これらは多様性を持つ地籍情 報の中の重要な一分野を提供できると考え

る。 